\title{
USING LITERATURE IN A COURSE \\ ON THE VIETNAM WAR
}

\author{
Jonathan Goldstein \\ West Georgia College
}

In sharing my experience with team-teaching a course on the Vietnam War, I hope to demonstrate that the inclusion of literary texts into the social science curriculum can strengthen both pedagogy and interest. Teachers of college courses that focus on other aspects of United States involvement in the world may find some of the experience applicable to their concerns. ${ }^{1}$

The Vietnam War course we taught at West Georgia College in 1984 and again in 1987 used textbooks by Stanley Karnow, Guenter Lewy, and George Herring. ${ }^{2}$ The vast body of war-related literary works in French, Vietnamese, and English was untapped as a classroom resource. While the Vietnam experience may not yet have produced a Red Badge of Courage, an All Quiet on the Western Front, a Naked and the Dead, or the multilingual masterpieces of the Spanish Civil War, it has evoked, as Joe Dunn has suggested, a volume of war literature in three languages that expands year by year. ${ }^{3}$ The remainder of this paper is my recommendation for a revised curriculum for our Vietnam course, using literature as a major component of the curriculum.

\section{WHY INCLUDE LITERARY WORKS IN A VIETNAM WAR COURSE?}

There seem to be two reasons why some of this literature should be incorporated into a Vietnam War course. The first is a general one that might apply to other history courses. Literary texts, when used as supplements to analytical histories and historical documents, can raise cultural and historical consciousness. They can be used to explore such themes as personal and national aggression, conflict of cultures, dislocation, restless alienation, tradition and modernization, exile, "self" versus "other," "civilized" versus "barbarian," "first" versus "third" world, mother country versus colonial periphery, or metropolis versus hinterland. A speculative approach in which questions are posed before students have read the texts can prepare students to look for those themes when they read. The texts then become the materials for finding some of the answers.

A second reason for including literary texts, while particular to the needs of West Georgia's course on the Vietnam War, may be relevant elsewhere. When the

${ }^{1}$ Copyright Jonathan Goldstein, 1988; used here with author's permission. This paper, prepared for the panel "Teaching the Vietnam War at the Secondary and Collegiate Levels," Southeast Association for Asian Studies, Charlotte, North Carolina, January 15, 1988, is a sequel to my 1985 Southeast Association for Asian Studies conference paper entitled "An Interdisciplinary Approach to Teaching the Vietnam War." Both papers are descriptions and analyses of an elective course first taught at West Georgia College in 1984. See: Jonathan Goldstein, "Teaching the American-Indochina War: An Interdisciplinary Experiment," Teaching History. A Journal of Methods 11, no. 1 (Spring 1987), 3-9.

${ }^{2}$ Stanley Karnow, Vietnam: A History (New York: Viking, 1984); Guenter Lewy, America in Vietnam (New York: Oxford University Press, 1980 [1978]); George Herring, America's Longest War: The United States and Vietnam, 1950-1975 (New York: Knopf, 1986 [1979]).

${ }^{3}$ Joe P. Dunn, The Vietnam Bookshelf Enters the 1980s," Naval War College Review 34, no. 5 (September-October 1981), 107-113. 
course was given in 1984 and 1987 no adjunct literary texts were assigned nor were students asked to do book reports using literary works of their own selection. Such lack is a serious pedagogical shortcoming because of the heavily mediated nature of the Vietnam War. As Robert Elegant, who reported on Southeast Asia for twenty years, has written in Encounter: "Vietnam was determined not only on the battlefield, but on the printed page, and above all, on the television screen." ${ }^{\text {th }}$ At West Georgia the audiovisual record of the war, especially the Public Broadcasting System series, was presented, discussed, and therefore seems to have been validated by the instructor. A student could leave the course legitimately wondering why no literature had emerged from the Vietnam War when there were so many movies, newsreels, and songs.

The 1984 and 1987 syllabi should be revised because of general theoretical and particular pedagogical concerns. All students could be assigned, as complements to the history texts, readings from the Vietnamese, French, and English literary responses to this war. To supplement the instructor's choice of texts, each student should be asked to choose literary works from any of the three relevant groups.

\section{THE REQUIRED READING OF THREE ADJUNCT TEXTS}

As in many teaching situations, the instructor's choice of canonical text is based on considerations of literary worth tempered by such practical realities as the cost of the books and the amount of time available for the reading. Given financial and time constraints at West Georgia, three inexpensive paperbacks, each under three hundred pages, plus a textbook and book(s) of the student's choosing for book reports, appear to be the maximum amount of reading that each student can be required to purchase, read, and discuss in class. ${ }^{5}$

\section{A Required French Text in Translation}

A good text dealing with the French colonial background is Marguerite Duras's The Sea Wall, first published in $1950 .{ }^{6}$ Duras's father was a French colonial official in Vietnam. Her account highlights an aspect of the French colonial experience that can be overlooked if one focuses on highly visible confrontations between the Légion Étrangère and Viet nationalists: the fate of the average French agricultural settler who went out to colonize. According to Duras, the settler was exploited on a different level than the Vietnamese. Before students have read Duras, they can be asked to look in other sources for evidence of "imperialistic

\footnotetext{
${ }^{4}$ Robert Elegant quoted in John Corry, "TV: The Tet Offensive in Vietnam," The New York Times, November 8, 1983, C15.

${ }^{5} \mathrm{~A}$ "buddy system" would be an experimental variant of this strategy. Under such a system, half the class might read text $3 \mathrm{~A}$, the other half of the class $3 \mathrm{~B}$, and then swap the books they have bought.

${ }^{6}$ Marguerite Duras, The Sea Wall, trans. Herma Briffault (New York: Farrar, Strus and Giroux, 1976 [1950]); Marguerite Duras, A Sea of Troubles, trans. Antonia White (Harmondsworth, England: Penguin, 1969 [1953]). For a novel on urban life in French Indochina, a possibility might be Duras's The Lover, trans. Barbara Bray (New York: Pantheon, 1985).
} 
exploitation." Most will find evidence of exploitation of Vietnamese by the French. After they have read the novel, their perspective can be broadened to encompass familial, inter-generational, and class conflict of French versus French. For example, in the Vietnamese colonial economy, a Michelin plantation executive or owner had as little empathy for the pureblooded French agriculturalist as for a Viet farmer. In telling the story of the trials and tribulations of French settlers Duras portrays exploitation and personal suffering as having universality--a non-nationalistic dimension that can be analyzed in the classroom.

\section{A Required English Language Text}

William J. Lederer and Eugene Burdick's The Ugly American picks up chronologically where Duras ends. ${ }^{7}$ The setting is the mythical Southeast Asian city of Haidho, Sarkhan, in the 1940s and early 1950s. France is on its way out and Americans, Soviets, and various political alignments of Sarkhanese vie for influence. A liquor-guzzling United States political reject serves as his nation's ambassador. His Machiavellian Soviet counterpart procures Sarkhanese goodwill by arranging to have sacks of donated American rice stamped "This is a gift from Russia." The ruse is especially successful since the stamp is in Sarkhanese, which most Americans cannot read. There is a single American with a grasp of the language and a noncondescending empathy for the people of Sarkhan. Frustrated by the combined efforts of bungling and historically-ignorant American bureaucrats, he is beset by the village-level machinations of the Communist/nationalist resistance. A poignant irony is that this aid worker's failure is orchestrated by his former Sarkhanese comrade from World War II days. Their close personal ties are repeatedly sundered by their ideological disputes over whether gradualist capitalism or revolutionary socialism is the better road to progress for Sarkhan.

Like Duras's novel, The Ugly American can be used in the classroom to highlight themes of personal, national, and international crisis and conflict. Another theme, not present in Duras, concerns how Americans should or should not conduct relations with Third World peoples, be they Vietnamese, Central Americans, or others. In both the fictionalized and non-fictionalized parts of The Ugly American Lederer and Burdick imply that United States foreign service personnel should have multi-lingual competence and should intensively study the history, geography, economy, and culture of the region to which they are assigned. American tours of duty should be lengthened on the Soviet model rather than subjected to abrupt, often highly-politicized, rotation.

The Ugly American was published in 1958, eight years after Duras's book, and before any substantial commitment of American ground troops in Vietnam. These were critical years of upheaval and crisis in which the crème de la crème of the French military was defeated on the Dien Bien Phu battlefield. During the same eight years, the United States fought Chinese and Korean troops and took on an increasingly militant counter-insurgency posture in Central America, especially in Guatemala. While these broader global conflicts are not explicitly discussed in The

${ }^{7}$ William J. Lederer and Eugene Burdick, The Ugly American, (New York: Ballatine, 1985 [1958]). 
Ugly American, their causation and parameters are alluded to in Lederer and Burdick's non-fictionalized, didactic last chapter. Like George Orwell's 1984, The Ugly American is timely, foreshadows the future, and stands on its own as a work of literary quality. The characters' concerns become our concerns.

For the more academically-motivated students, an alternative text to Lederer and Burdick is Graham Greene's The Quiet American. ${ }^{8}$ Like Burdick and Lederer, Greene wrote a fast-moving account of what took place just as the French were leaving Indochina and Americans were arriving. There the similarities end. Greene, unlike Lederer and Burdick, resided extensively in Vietnam in the 1950s. He draws on his own experience to create believable characters in a vivid Vietnamese setting rather than cardboard characters in an exotic locale. Greene's protagonist, an English journalist, explores the alleys, boulevards, whorehouses, and wharfsides of Hanoi and Saigon. He visits battlefields and flies a bombing run up Hanoi's Red River valley. Unlike Lederer and Burdick, Greene's cynical correspondent sees no "goodies". and "baddies" and espouses no highly-dichotomized, Cold War world view. He is skeptical of all governmental schemes, especially of the efforts of an idealistic American who wishes to channel aid to a "third force" as France departs. Of this person, the correspondent concludes: "I never knew a man who had better motives for all the trouble he caused."

\section{A Required Text in Translation from the Socialist Republic of Vietnam}

It is a formidable task to find a readily available inexpensive classroom text coming from or reflective of the viewpoint of the Socialist Republic of Vietnam, hereafter referred to as "SRV." One must distinguish between literature written and published in the SRV versus Vietnamese expatriate literature. Each genre has its own value when used critically in the classroom. The two forms can be juxtaposed much in the way that an American history instructor might contrast literary works by an American Revolutionary and a Tory.

With respect to the literature of the SRV, much has been written in Vietnamese and published there in journalistic fashion. Additionally, Hanoi's Red River Publishing House has published in English Nguyen Khac Vien and Hu Ngoc's mammoth, $31^{\prime \prime}$ thick anthology Vietnamese Literature. Anh Duc's Hon Dat is an example of a Vietnamese novel written during the American-Indochina War. ${ }^{9}$ For reasons of availability, neither of these works would be appropriate for an American classroom. Relatively little that has been translated into English has found effective distribution in the United States. The card catalog of the National Library in Hanoi

${ }^{8}$ Graham Greene, The Quiet American (New York and Harmondsworth, England: Penguin, 1980 [1955]). A third alternative to Burdick and Lederer is the Englishman Mark Frankland's semiautobiographical novel The Mother-of-Pearl Men (London: John Murray, 1985).

\footnotetext{
${ }^{9}$ Nguyen Khac Vien and Hu Ngoc, Vietnamese Literature (Hanoi: Red River Publishing House, 1982); Anh Duc, Hon Dat, trans. Robert C. Friend (Hanoi: Foreign Languages Publishing House, 1969). For a general critique of Vietnamese literature, historical and contemporary, see Maurice Durand and Nguyen Tran Huan, An Introduction to Vietnamese Literature (New York: Columbia University Press, 1985).
} 
lists hundreds of editions of English language works produced by Red River Publishing House and affiliated publishers. Until Sino-Vietnamese hostilities began in 1978-79, Americans could purchase Vietnamese literature in translation through the semi-official outlet for People's Republic of China publications in the United States, China Books and Periodicals. ${ }^{10}$ Since the outbreak of that war, American sources for SRV literature in translation have been largely restricted to the Asia Resource Center, the U.S.-Vietnam Friendship Association, and the U.S./Vietnam Friendship and Aid Association of Southern California. ${ }^{11}$ These organizations are staffed mainly by volunteers and are sources for occasional single, photo copies-but rarely class sets--of SRV literature.

If and when the United States recognizes the SRV and lifts its embargo on trade with that nation, an important component of the third major linguistic tradition that overarches the Vietnam conflict may become more accessible to American teachers and students. Until then one can fall back on autobiography for a text from the SRV. Perhaps the most important military figure in twentieth century Vietnam, General Vo Nguyen Giap, published his 110-page autobiographical account Dien Bien Phu in Hanoi in approximately 1955 . Originally issued by Foreign Languages Press, the work has been reprinted in numerous editions. It is available in paperback as pages 131-88 of People's War People's Army with a foreword by Roger Hilsman. ${ }^{12}$ It is Giap's personal reminiscence of the military and political techniques he used against the French. His theme is an abiding nationalism. He sees native ingenuity as the essential quality that enabled the Vietnamese to defeat the Mongols. The Vietnamese cleverly drove stakes into the Bach Dang River to impale the invaders' warships. An intimate knowledge of terrain helped the Vietnamese achieve what many Westerners perceived as an "impossible task": carrying heavy artillery pieces across the mountains to Dien Bien Phu. To Giap, indomitable courage enabled the Vietnamese to mount human-wave suicide charges and to tunnel under French fortifications. Finally, according to him, Marxist ideology and party discipline additionally enabled a victory of a so-called "underdeveloped" Third World people over a "mighty" first-world foe. ${ }^{13}$

Whether one assigns Giap, Greene, Lederer and Burdick, or Duras, certain teaching strategies can be applied to some or all of these readings. One strategy suggested by Douglas Simon of Drew University is to assign The Ugly American to students before they have read a single textbook page or have viewed any of the

\footnotetext{
${ }^{10}$ China Books and Periodicals, Inc., is registered under the Foreign Agents Registration Act as an agent of the People's Republic of China.

${ }^{11}$ Published materials from the Socialist Republic of Vietnam are available in the United States from Asia Resource Center, P.O. Box 15275, Washington, D.C. 20003, TEL: (202) 547-1114; The U.S.Vietnam Friendship and Aid Association of Southern California, P.O. Box 453, Murrieta, CA 92362, TEL: (714) 677-5905; and The U.S./Vietnam Friendship Association, P.O. Box 5043, San Francisco, CA 94101. The brochure English Language Publications from Vietnam is available from the Murrieta, California, association.
}

${ }^{12}$ New York: Bantam, 1968.

${ }^{13}$ As a foil to Giap's internationally-publicized official history, a professor might wish to assign a contrasting interpretation of the battle. See Ronald H. Spector, "In the Nam and Back in the World: Vietnamese Sources on the Vietnam War, "The Joumal of American History, 75, no. 1 (June 1988), 213. 
Public Broadcasting System's Vietnam series. Students would be asked to write down and discuss the major points, lessons, and predictions of the book and then to "file away" these ideas. The class would return to the ideas a couple of weeks later or at the end of the course. At that time students would attempt to determine the validity of Lederer and Burdick's major points. How prophetic were these two authors?

A variant on Professor Simon's strategy would be to pose specific speculative questions before students have read their assignments. Were there any pre-1954 "lessons of Vietnamese history" that should have tempered America's post-1954 policies in that region? Were there any "un-learned lessons" of the battle of Dien Bien Phu? Younger American officers certainly read Giap's book prior to massive United States involvement and took him seriously as a strategist who defeated the French. ${ }^{14}$ Giap used some of the same tactics against the Americans. Why did Americans not believe these strategies would succeed against the United States? Was the United States's role in Vietnam simply wrong on all counts? Do the Vietnamese or American texts contribute any specific information that can help us to better answer that question? These questions can serve as bases for class discussion after the required texts have been read. They broaden a discussion of international relations and raise issues of American ethnocentricity and racism, professional myopia, perceptions of not being a colonial power like France, and overconfidence in having an overwhelmingly favorable balance of military forces.

\section{A BOOK REPORT ON TEXT(S) OF THE STUDENT'S CHOICE}

The instructor's selection of three literary texts to complement the textbook had been described as a privileged choice based on practical, financial, as well as pedagogical, considerations. Each of the three texts has also been chosen for its lucidity. Philip Brown, who used Lederer and Burdick in a Vietnam course at the University of North Carolina in Charlotte, included on his syllabus the phrase "most students have found L \& B good reading when they want to relax."15

To supplement the choices of the instructor, each student should be asked to select either one full-length novel or two shorter literary works from any of the three groups. He or she would then prepare a four-to-eight page analysis in which each of the following questions would be answered with reference to the Vietnam War:

What subject matter does each author cover?

How does each handle this subject matter?

What is the major thrust or interpretation of each book?

\footnotetext{
${ }^{14}$ Colonel Harry Summers has argued that it was not Giap's strategy as laid out in People's War People's Army that brought victory for the Vietnamese revolution but rather a conventional offensive launched from the North against which American arms had been quite effective up to 1973. Harry G. Summers, Jr., On Strategy: A Critical Analysis of the Vietnam War (New York: Dell, 1984). See also William C. Westmoreland, A Soldier Reports (New York: Dell, 1980 [1976]), 67, 359, 364, 536-37.
}

${ }^{15}$ Printed syllabus. 
What issues, if any, are subordinated to bring out the main focus?

What are the writer's sources of information?

What are the author's biases? How do you know?

What basic assumptions does each writer make about the indigenous

history of Vietnam? About Westerners in Vietnam?

How do you rate the author(s) in terms of style, clarity, and persuasiveness?

Three specialized categories of Vietnam War literature from which students could select collateral reading remain to be discussed: Vietnamese expatriate texts; episodic novels; and texts that lend themselves to comparative analysis in book report form.

\section{Vietnamese Expatriate Texts}

You might wish to recommend a Vietnamese expatriate literary text to more academically-motivated students. Two major works of this type of fiction have been translated and are readily available in the United States.

Pham Van Ky's Blood Brothers was originally written in 1947 in French. ${ }^{16} \mathrm{Ky}$ 's major focus is on tradition and change at the village level, forces personified in the attitudes and behavior of two of the narrator's "blood brothers." One brother espouses traditional Taoist mysticism, the Chinese philosophy of inaction (wu wei), passivity, and asceticism. Another brother adopts Marxist ideology and joins the Viet Minh. The narrator finds himself in a dilemma. He is unable to choose between friends and brothers and between Vietnamese traditionalism and a radical form of modernization. The second half of his dilemma is also what Vietnamese society as a whole must confront from 1945 on.

A second Vietnamese expatriate novel that might be considered for class use is Tran Van Dinh's Blue Dragon. White Tiger. A Tet Story, originally written in Vietnamese and available in English translation only as a 334-page hardback. ${ }^{17}$ Because of cost and length it may be less appropriate for classroom use than Ky's shorter and less expensive paperback.

Dinh's work explicates the motif of a "Blue Dragon," representing the East, spring, and tenderness, in conflict with a "White Tiger," symbolizing the West, winter, and force. The novel focuses on the 1960s and 1970s through the eyes of a Vietnamese diplomat who resigns his post to protest the anti-Buddhist policies of the Ngo Dinh Diem regime. Minh joins the Viet Cong and rises to prominence in that organization. Ultimately he comes to see them, also, as a force that stifles

\footnotetext{
${ }^{16}$ Pham Van Ky, Blood Brothers, trans. Margaret Maudon (New Haven: Council for Southeast Asia Studies, Yale Center for International and Area Studies, 1987). A comprehensive introduction, footnotes, and appendix have been prepared by Lucy Nguyen. This book also includes numerous advertisements for translations into English of other Vietnamese works. On Vietnamese expatriate literature see articles in The Vietnam Forum (New Haven, CT) and David M. Berman, "Vietnam Through Vietnamese Eyes: A Review of the Literature," Asia Pacific Community (Tokyo), Spring 1985, 88-104.
}

${ }^{17}$ Philadelphia: TriAm Press, 1983. 
traditional Vietnamese culture. He flees Vietnam as one of the "boat people" and winds up as a refugee in the United States. Dinh includes excerpts from Vietnamese poetry, songs, inscriptions, and histories. In addition to what Dinh includes, a wide variety of these types of non-novelistic Vietnamese literature is readily available in English translation for classroom use. ${ }^{18}$

\section{Episodic Novels as Collateral Reading}

Long, episodic novels can be useful in teaching a Vietnam War course in at least two ways. A primary reason for assigning episodic novels is their lucidity. They have the potential for sustaining less academically-motivated students' interest in history--an enthusiasm that may have been kindled by required books like The Ugly American. Episodic novels may "turn on" students otherwise "turned off" to history.

A second reason for including episodic novels is their substance. All of the novels previously discussed in this paper that were originally written in English (as opposed to novels translated into English) share one characteristic. As Gerald Berkley pointed out at a 1985 symposium on teaching the Vietnam War, while there are well over a hundred English-language novels that have Vietnam as their primary focus, in almost all of them Vietnamese characters are either absent, peripheral, or drawn from Western stereotypes. ${ }^{19}$ Two episodic English language novels extensively feature Vietnamese as well as Western experiences during the French and to a lesser extent the American involvements in Vietnam.

Michael Peterson's The Immortal Dragon is an extravaganza of intrigue taking place in France and Vietnam between 1847 and 1914 as the mother country tried to consolidate her Southeast Asian empire. ${ }^{20}$ The novel traces the life of André, a

\footnotetext{
${ }^{18}$ Whether or not one uses Dinh's novel with its excerpts of Vietnamese poetry and songs, the assigning of this type of collateral reading can expand a student's awareness of Vietnamese culture. A new novel by Dinh is No Passenger on the River (Fort Collins CO: Pratt, 1989). Among nonnovelistic Vietnamese literary works readily available in the United States in English translation are: 1) three collections of historical poetry including some poems by Ho Chi Minh [Huynh Sanh Thong, trans. and ed., The Heritage of Vietnamese Poetry (New Haven: Yale University Press, 1979); Nguyen Ngoc Bich, trans. and ed., with Burton Raffel and W.S. Merwin, A Thousand Years of Vietnamese Poetry (New York: Knopf, 1975); and Burton Raffel, trans., From the Vietnamese: Ten Centuries of Poetry (New York: October House, 1968). From the Vietnamese includes eleven prison poems of Ho Chi Minh.]; 2) four translations of contemporary Vietnamese poetry [Nhat Nahn and Vo-Dinh, Zen Poems (Greensboro NC: Unicom Press, 1976); Nhat Hanh, Viet Nam Poems, trans. Nhat Nahn and Helen Coutant (Santa Barbara CA: Unicorn Press, 1972); Thich Nhat Nahn and Vo-Dinh, The Cry of Vietnam (Santa Barbara CA: Unicorn Press, 1968); and Don Luce, John C. Shafer, and Jacquelyn Chagnon, eds., We Promise One Another, Poems from an Asian War (Washington DC: Indochina Mobile Education Project, 1971)]; 3) a bilingual anthology of Vietnamese folk poetry [John Balaban, trans. and ed., Ca Dao Vietnam: A Bilingual Anthology of Vietnamese Folk Poetry (Greensboro NC: Unicorn Press, 1980)]; and 4) a translation of the eighteenth-century Vietnamese poet, Nguyen Du, The Tale of Kieu, trans. Huynh Sanh Thong (New Haven: Yale University Press paperback, 1987)]. Du is also represented in the aforementioned Nguyen and Hu anthology published in Hanoi and in We Promise One Another.

${ }^{19}$ Gerald W. Berkley, "Novels About the 'Other Side' in the War in Vietnam." Unpub. paper presented at the Southeast Conference, Association for Asian Studies, Durham NC, January 17-19, 1985, 1.
}

${ }^{20}$ Michael Peterson, The Immortal Dragon (New York: New American Library paperback, 1983). 
French colon, and his extended French, Vietnamese, and mixed-race family. Most prominent among the Vietnamese with whom Andre and his kin interact is Ahn, a mandarin whose fervent nationalism alienates him from Emperor Tu Duc.

Peterson explores the complexity of behavior as Vietnamese try to define and pursue the dragon's virtue. Emperor Tu Duc sees collaboration with France as a means of preserving at least part of his kingdom. That, to him, is a virtue. Ahn defines virtue differently and admonishes the Emperor that "our people will never be subjugated. A thousand years of Chinese (rule) proved that, and these silly pale people from afar have no hope of dominating us. ${ }^{21}$ Resistance is the proper course of action.

Peterson's examination of these social conflicts is the strength of his book. On the other hand, he garnishes his tale with almost non-stop sexual and sexist episodes, perhaps gearing his script for a potential TV miniseries or for a cinema audience. The sheer volume of gratuitous sex in The Immortal Dragon may make this novel inappropriate for some students, communities, or educational systems. From that standpoint alone, the British journalist Anthony Grey's less sexually explicit Saigon may be more appropriate than The Immortal Dragon.

Grey picks up roughly where Peterson ends, covering the years 1925 to $1975 .^{22}$ He also traces one fictionalized Western family's interaction with Vietnamese counterparts. Beginning with Chuck Sherman's death on a Vietnam hunting expedition in the 1920s and ending with the evacuation of an illegitimate Sherman offspring during the 1975 Battle of Saigon, the novel provides a panorama of urban and rural Vietnamese life from the elaborate court at Hué to the plantations and villages to the fetid Chinese ghetto of Cholon.

As already noted, Grey and Peterson emphasize the French colonial era. Students who wish to focus more on the American experience, or students who are more academically motivated and who can handle two books rather than reading a single episodic novel, can be given the opportunity to write a comparative book report rather than writing a book report based on a single volume.

\section{A Comparative Book Report of Two Contrasting Texts}

A student selecting this option would have to select some comparativist framework and make it clear to the instructor. The vast and expanding volume of American literature of the Vietnam War makes this approach viable. ${ }^{23}$ The literature is sufficiently large that students can criss-cross ideological, racial, and

${ }^{21}$ Peterson, Immortal Dragon, 163.

${ }^{22}$ Anthony Grey, Saigon (New York: Dell paperback 1983 [1982]).

${ }^{23} \mathrm{~A}$ student is able to choose from a wide range of available texts to develop his or her comparativist framework. Apart from college and public libraries, the B. Dalton bookstore chain has installed a "Vietnam Books" paperback section in its outlets nationwide. There are at least three American book dealers who specialize in Vietnam War literature: Ken Lopez, 51 Huntington Road, Hadley MA 01035, TEL: (413) 584-4827; Dalley Book Service, 90 Kimball Lane, Christiansburg, VA, 24073; and Vietnam Bookstore, P.O. Box 469, Collinsville CT 06022, which also publishes a catalog and newsletter. 
gender considerations. ${ }^{24}$ For example, one can readily contrast, based on literature, pro and antiwar sensitivities of women who served in Vietnam, both in the military and in the voluntary agencies. ${ }^{25}$ Black versus white P.O.W. accounts can be compared. . $^{26}$

In conclusion, the episodic novel, comparative book report, or three seminal texts representing the major groups of Vietnam war literature can offer students a richer experience than they might have had while restricted to textbooks plus audiovisual accounts. The selection by the instructor of three lucid texts capitalizes on students' enthusiasm and directs it toward clarification of issues that are both highly controversial and relevant in their lives. The addition of an expatriate or episodic novel or other texts of the students' choice furthers their value clarification process and mitigates against their adoption of only the world view presented in texts assigned by the instructor.

Vietnam veteran and education professor David Berman lamented in a recent issue of The Social Studies that "it is unfortunate that our approach to the teaching

\footnotetext{
${ }^{24}$ To assist students in coming to grips with the abundance of American literature on the Vietnam War, there are several standard references on the subject. Catherine Calloway and Arthur Casciato's bibliographies of criticism of American Viet War literature include subsections on poetry, prose, and drama. Catherine Calloway, "Vietnam War Literature and Film: A Bibliography of Secondary Sources," Bulletin of Bibliography 43, no. 3 (September 1986), 149-158; Arthur D. Casciato, "Teaching the Literature of the Vietnam War," Review (Charlottesville VA, 1987), 9, 125-147. For listings of titles of Vietnam War literature, students can consult Tom Colonnese and Jerry Hogan's comprehensive bibliography of novels, poetry, plays, short stories, and journalistic works containing some fiction. Tom Colonnese and Jerry Hogan, "Vietnam War Literature, 1958-1979: A First Checklist," Bulletin of Bibliography 38, no. 1 (January-March 1981), 26-31, 51. Other general literary bibliographies and critiques: John Clark Pratt, "Bibliographic Commentary," in Timothy Lomperis, "Reading the Wind" The Literature of the Vietnam War (Durham NC: Duke University Press, 1987); Edward F. Palm, "Novels of Vietnam and the Uses of War Literature," Marine Corps Literature (Metuchen NJ: Scarecrow Press, 1982); Margaret E. Stewart, "Vietnam-War Novels in the Classroom," Teaching History 6, no. 2 (Fall, 1981), 60-66; and Philip Beidler,, American Literature and the Experience of Vetnam (Athens, GA: University of Georgia Press, 1982).

There are also specialized bibliographical resources. Jeffrey Fenn has analyzed American plays pertaining to the Vietnam War; William Ehrhart has anthologized poetry; and Nancy Anisfeld has compiled a reader containing novel and drama excerpts, short stories, and poetry, Jeffrey W. Fenn, "Culture Under Stress: American Drama and the Vietnam War." Unpub. Ph.D. diss., Theater, University of British Columbia, 1988; William D. Ehrhart, ed., Carrying the Darkness (New York: Avon, 1985); Nancy Anisfeld, ed., Vietnam Anthology: American War Literature (Bowling Green, OH: Bowling Green State University Popular Press, 1987).

${ }^{25}$ On Vietnamese and American women during the Vietnam War, see: Patricia L. Walsh Forever Sad the Hearts (New York: Avon, 1982); Linda Van Devanter and Christopher Morgan, Home Before Morning (New York: Beaufort, 1983; New York: Warner, 1984); Wendy Larsen and Tran Thi Nga, Shallow Graves: Two Women and Vietnam (New York: Harper \& Row, 1985).
}

${ }^{26}$ Students curious about racism can consult Gerald Gill's "Black Soldiers Perspectives on the War in Vietnam," Indochina Newsletter (Cambridge MA), January-February, 1984. Students who like prisoner of war accounts can find comprehensive bibliographies in Joe P. Dunn's "The POW Chronicles: A Bibliographic Review," Armed Forces and Society 9, no. 3 (Spring, 1983), 495-514, and in Dunn's "The Vietnam War POW/MIAs: An Annotated Bibliography," Bulletin of Bibliography 45, no. 2 (June, 1988), 152-157. 
of Vietnam is primarily through the American lens." ${ }^{\text {27 }}$ The need that Berman highlights can be filled by juxtaposing Western and non-Western literatures. In that fashion students' world outlook and empathy for "the other" may be broadened and sensitized. The insertion of world literature into a history course might then, in the long run, even have redeeming features for society as a whole.

${ }^{27}$ David M. Berman, "Perspectives on the Teaching of Vietnam," The Social Studies 7 , no. 4 (July/August 1986), 165. See also David M. Berman, 'Every Vietnamese Was a Gook': My Lai, Vietnam, and American Education," Theory and Research in Social Education 1G no. 2 (Spring, 1988), 141-59. 